UDC: $616.62-003.7+616.71-007.234]-084$

https://doi.org/10.32345/USMYJ.4(127).2021.38-43

Received: August 17,2021

Accepted: November 19,2021

\title{
KIDNEY STONE DISEASE AND OSTEOPOROSIS - TOPIC ISSUES OF COMORBIDITY
}

\author{
Kordubailo Ilia', Nikitin Oleg ${ }^{2}$, Nishkumay Olga ${ }^{3}$, Samchuk Pavlo ${ }^{4}$ \\ ${ }^{1}$ Student of Bogomolets National Medical University, Ukraine \\ ${ }^{2}$ Professor, Doctor of Medicine, Acting Head of the Department Urology Bogomolets National Medical \\ University, Ukraine \\ ${ }^{3}$ Doctor of Medicine, Professor of the Department Internal Medicine №2 Bogomolets National Medical \\ University, Ukraine \\ ${ }^{4}$ PhD, Assistant of the Department Urology Bogomolets National Medical University, Ukraine
}

\begin{abstract}
KSD) and osteoporosis $(O P)$ increases every year. In the prevention of osteoporosis, it is important to consume a sufficient amount of calcium-rich foods in the daily diet, as well as the use of calcium. One of the important reasons for the insufficient use of calcium-containing products and medicines is the anxiety not only of patients, but, very importantly, of doctors as much as possible. This has serious justification, as nephrolithiasis occurs in approximately 5\% of the population, and the risk of developing kidney stones during life is $8-10 \%$. It is believed that secondary hyperparathyroidism, which is caused by hypocalcemia due to insufficient consumption of calcium-containing products and impaired renal function, leads to increased bone resorption, formation of kidney stone disease. It is important to consider that against the background of hypertensive, atherosclerotic kidney disease, tubulo-interstitial lesions of the kidneys with decreasing glomerular filtration rate decreases the synthesis of 1 $\alpha$-hydroxylase - an enzyme by which 25-hydroxycholecalciferol (25 (OH) active D3, calcium) form of vitamin D3-1.25 dihydroxycholecalciferol (1.25 (OH) 2D3, calcitriol - D-hormone) and secondary hyperparathyroidism develops. In this case, the purpose of correction along with the treatment of urolithiasis (spa treatment, given the attendance of the presence of KSD, to carry out the distance lithotripsy), intake of active metabolites of vitamin D (should be started with low doses, independent of the initial PTH concentration, and then titrated based on the PTH response) conducting X-ray densitometry.
\end{abstract}

Key words: urolithiasis, osteoporosis, hyperparathyroidism, calcitriol.

Introduction. The prevalence of kidney stone disease (KSD) and osteoporosis (OP) is increasing every year. It is proved that today the prevalence of OP has reached the character of a global epidemic - in older women is $20-39 \%$, in men - 9-23\% (Rendina et al., 2020). In the prevention of osteoporosis, it is important to consume a sufficient amount of calcium-rich foods in the daily diet, as well as the use of calcium. However, less than $30 \%$ of patients actually receive prophylactic treatment (Harvey et al., 2017).

One of the important reasons for the insufficient use of calcium-rich products and medicines is the anxiety not only of patients, but, very important, of doctors, regarding possible provocation or development of kidney stone disease. This is a serious justification nephrolithiasis occurs in approximately $5 \%$ of the population, and the risk of developing kidney stones during life is $8-10 \%$. In men, kidney stone formation occurs 2 times more often than in women. The most common KSD in men is over 30 years. Women are characterized by two peaks - at the age of 35 and in the postmenopausal pe- riod. The presence of KSD increases the probability of formation of a new concretion within 10 years by $50 \%$.

The given examples indicate the topicality of the issues of management of patients with comorbid pathology - KSD and disorders of bone mineral density for the treatment of bone tissue as for its treatment calcium and vitamin $\mathrm{D}$ are prescribed. However, according to patients and some doctors, the use of additional calcium supplements can provoke the development or progression of KSD. However, in most cases, both osteoporosis and the formation of stones do not occur as a result of prophylactic calcium supplement, on the contrary, as a result of insufficient content of calcium and vitamin D in the blood and the development of secondary hyperparathyroidism (Cheng et al., 2017). According to the hypotheses, the calcification of blood vessels is one of the risk factors for the development of cardiovascular disasters, as well as the development of KSD, which increases the development of osteoporosis by releasing of calcium from the bone tissue and its accumulation in vessels and kidneys (Rendina et al.,2020). It is thought 
the $25(\mathrm{OH})$ vitamin $\mathrm{D}$ deficiency and the consequences of this, secondary hyperparathyroidism one of the mechanisms of calcification of blood vessels and the development of KSD (Taguchi et al., 2020).

The precursor of cholecalciferol, provitamin D3, is synthesized in the epidermis from provitamin D3 (7-dehydrocholesterol) under the influence of ultraviolet light. Provitamin D3 is converted to cholecalciferol by thermal isomerization (at body temperature). In the epidermis, cholecalciferol binds to vitamin D-binding protein and in this form enters the bloodstream and is transferred to the liver. Vitamin-D-binding protein transports other derivatives of cholecalciferol and ergocalciferol, including $1.25(\mathrm{OH}) 2 \mathrm{D} 3$. Cholecalciferol is found in many products. It is especially rich in fish oil, liver of birds, birds and fish, as well as in egg white. Ergocalciferol is formed in the cells of ergosterol plants. Cholecalciferol and ergocalciferol are hormonally inactive. In the liver, cholecalciferol and ergocalciferol are converted to $25(\mathrm{OH})$ D3 (25-hydroxyvitamin D3, calcidiol) by 25-hydroxylation. $25(\mathrm{OH}) \mathrm{D} 3$ - the main circulating metabolite of cholecalciferol and ergocalciferol. Therefore, the concentration of $25(\mathrm{OH}) \mathrm{D} 3$ can be judged by the content in the body of all forms of vitamin D. Formed $25(\mathrm{OH}) \mathrm{D} 3$ in combination with vitamin-D-binding protein in cells of proximal convoluted tubules, $25(\mathrm{OH}) \mathrm{D} 3$ undergoes hydroxylation. As a result, a hormonally active form of vitamin D-1,25 (OH)2D3 (calcitriol - D-hormone) is formed, which is catalyzed by the mitochondrial enzyme 1- $\alpha$ hydroxylase (Cheng et al., 2017). Like PTH, the D-hormone calcitriol-1.25 $(\mathrm{OH}) 2 \mathrm{D} 3$ regulates bone remodeling and stimulates calcium absorption in the intestine thereby supporting mineralization. When it is in deficiency, rickets or osteomalacia develop (Povoroznyuk et al., 2017). As a result of hypocalcemia or vitamin D deficiency, parathyroid hormone $(\mathrm{PTH})$ production is activated. Increasing the level of PTH raise the activity of osteoclasts, which enhance bone resorption. This effect is mediated by osteoblasts: under the influence of PTH, they begin to forcibly secrete proinflammatory cytokines (IL-1), which have osteoclast-activating properties. As a result of bone resorption, the concentration of calcium in the serum increases as early as 30-60 minutes after the secretion of PTH. At constantly increased level of PTH (at a hyperparathyroidism) resorption of a bone tissue prevails over formation that leads to decrease mineral density. It is assumed that the increased resorption of bone tissue in hyperparathyroidism is caused not only by the activation of proinflammatory cytokines, but also by accelerated proliferation of osteoclast progenitor cells. Parathyroid hormone stimulates the production of components of the organic matrix by osteoblasts. Therefore, with short-term periodic administration of PTH (for several days), its anabolic effect is manifested - the formation of bone tissue. Parathyroid hormone stimulates calcium reabsorption in distal convoluted tubules and thereby reduces calcium excretion in the urine, inhibits tubular phosphate reabsorption and phosphate reabsorption. In addition, it stimulates the synthesis of $1.25(\mathrm{OH}) 2 \mathrm{D} 3$ from $25(\mathrm{OH}) \mathrm{D} 3$ in the proximal convoluted tubules, which enhances the absorption of calcium in the small intestine. Secondary hyperparathyroidism, which is caused by hypocalcemia as a result of increased resorption, leads to the formation of a matrix with subsequent formation of microliths. Thus, not taking calcium supplements, and hypocalcemia in most cases leads to secondary hyperparathyroidism and increases the risk of KSD (Khan et al., 2017).

There are currently guidelines for the treatment of osteoporosis in patients with CKD. There are no clear guidelines for the management of patients with concomitant KSD, CKD, and varying degrees of bone mineral density disorders, for example, in osteopenia.

Purpose of work: to consider tactics of management of the patient with a comorbid pathology - various degree of disturbance of mineral density of a bone and kidney stone disease on clinical examples.

\section{Descriptions of clinical cases.}

\section{Clinical case 1.}

Patient M. is 72 years old, menopausal period is 40 years old (physiological). No complaints, she applied for a routine check-up to rule out osteoporosis. History: KSD (right kidney stone, size 9 by $5 \mathrm{~mm}$ ), chronic calculous pyelonephritis in remission. Risk factors of osteoporosis: age over 50 years, hip fracture in the mother, menopause 40 years, insufficient consumption of calcium-containing products ( less than $200 \mathrm{mg}$ per day). Biochemical study: ionized calcium $1.21 \mathrm{mmol} / \mathrm{l}$, phosphorus $1.2 \mathrm{mmol} / \mathrm{l}$, PTH $88.4 \mathrm{pmol} / \mathrm{l}$, creatinine $78 \mu \mathrm{mol} / \mathrm{l}$, glomerular filtration rate (GFR) $66,0 \mathrm{ml} /$ $\mathrm{min} / 73 \mathrm{~m}^{2}$. Conclusion of the X-ray densitometry: deviation of the mineral density T-score index of bone tissue within the age norm. (Fig. 1).

Recommendations: The tactic of managing this patient from the point of view of a urologist, given the attendance of the presence of KSD, is to carry out the distance lithotripsy. In the future, prophylactic use of calcium and vitamin D supplements is necessary for the prevention of osteoporosis and bone fractures. Patient has secondary hyperparathyroidism prophylactic intake of active metabolites of vitamin D (should be started with low doses, independent of the initial PTH concentration, and then titrated based on the PTH response), because the normal level of blood creatinine and decrease the GFR. In the future - the monitoring of the level of ionized calcium, phosphorus.

\section{Clinical case 2.}

Patient T., 73 years old, menopausal period 50 years old (surgical). Complaints: permanent pain in the thoracic, lumbar spine. Anamnesis morbi: KSD (stone of the right ureter, which disrupts the outflow of urine). In 
UKRAINIAN SCIENTIFIC CENTER OF OSTEOPOROSIS PROBLEM

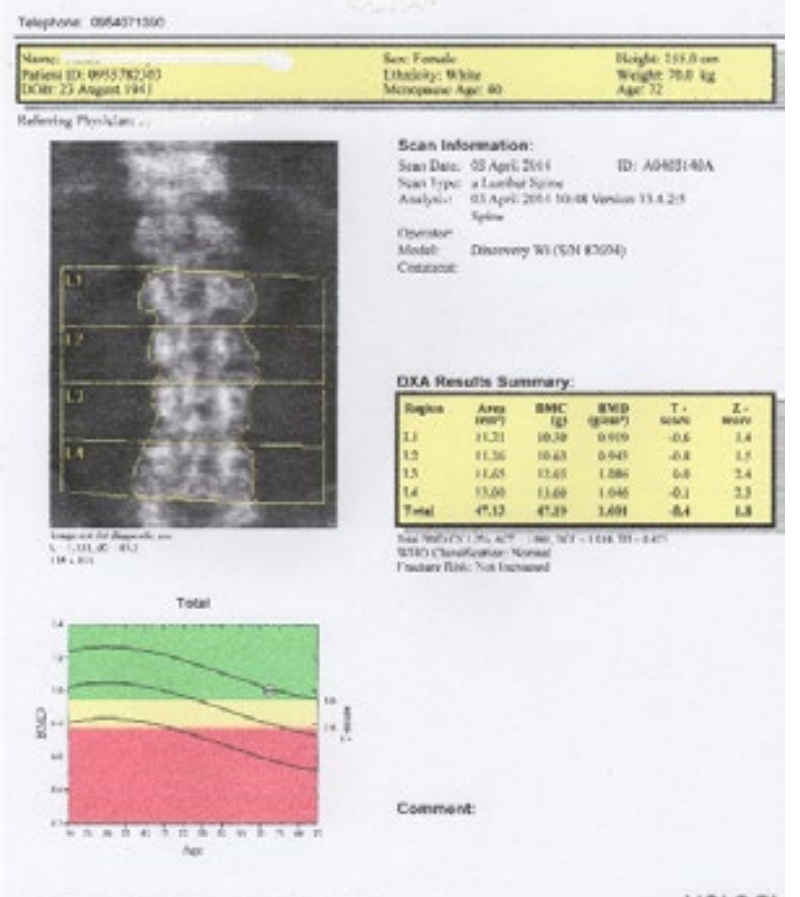

Fig.1. X-ray absorptiometry protocol of the patient M.

1980, a ureterolithotomy was performed on the left (removed oxalate stone, size $1.1 \times 0.5 \mathrm{~cm}$ ). The patient had a bone compression fracture of L2, L3 of low-energy character (falling from his height). Biochemical study: ionized calcium - $1.22 \mathrm{mmol} / \mathrm{l}$ phosphorus - $0.98 \mathrm{mmol}$ /1, PTH - $97.2 \mathrm{pmol} / \mathrm{l}$, creatinine $88 \mu \mathrm{mol} / 1$, GFR - 56 $\mathrm{ml} / \mathrm{min} / 1,73 \mathrm{~m}^{2}$. Conclusion of the X-ray densitometry (Fig. 2): the deviation of the bone mineral density index (T-score) corresponds to osteoporosis.

Recommendations: a drug for the treatment of osteoporosis, calcium, vitamin D supplements. Given the attendance of the lowered GFR (at normal level of blood creatinine) the patient was prescribed active metabolites of vitamin D ( should be started with low doses, independent of the initial PTH concentration, and then titrated based on the PTH response. Hypercalcemia should be avoided), medication for the treatment of osteoporosis with further monitoring of the level of ionized calcium, phosphorus, blood parathyroid hormone. From the point of view of metaphylaxis of KSD - treatment is not demanded, appointment with the purpose of prophylaxis of citrate mixes (Uralit-U, Blemaren) under monitoring of the urine $\mathrm{pH}$ is recommended.

\section{Clinical case 3 .}

Patient K, 23 years old, menopausal period 3 years (surgical). Anamnesis morbi: KSD (recurrent coral-like stone of the left kidney), chronic calculous pyelonephritis in the stage of unstable remission. Biochemical

\section{UKRAINIAN SCIENTIFIC CENTER OF OSTEOPOROSIS PROBLEM}

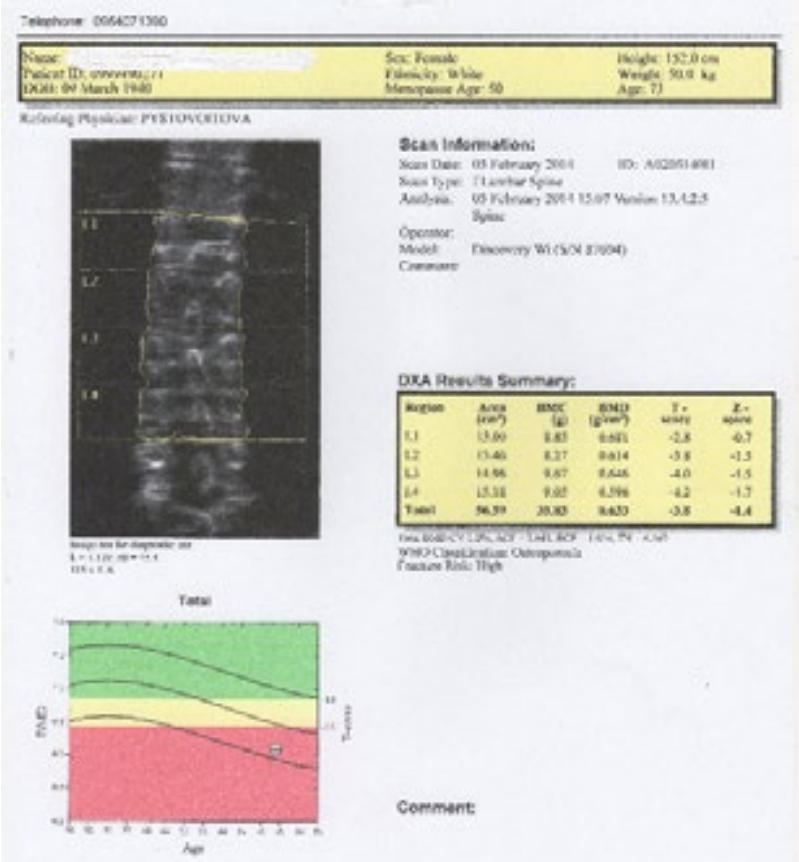

HOLOGIC

Fig.2. X-ray absorptiometry protocol of the patient T.

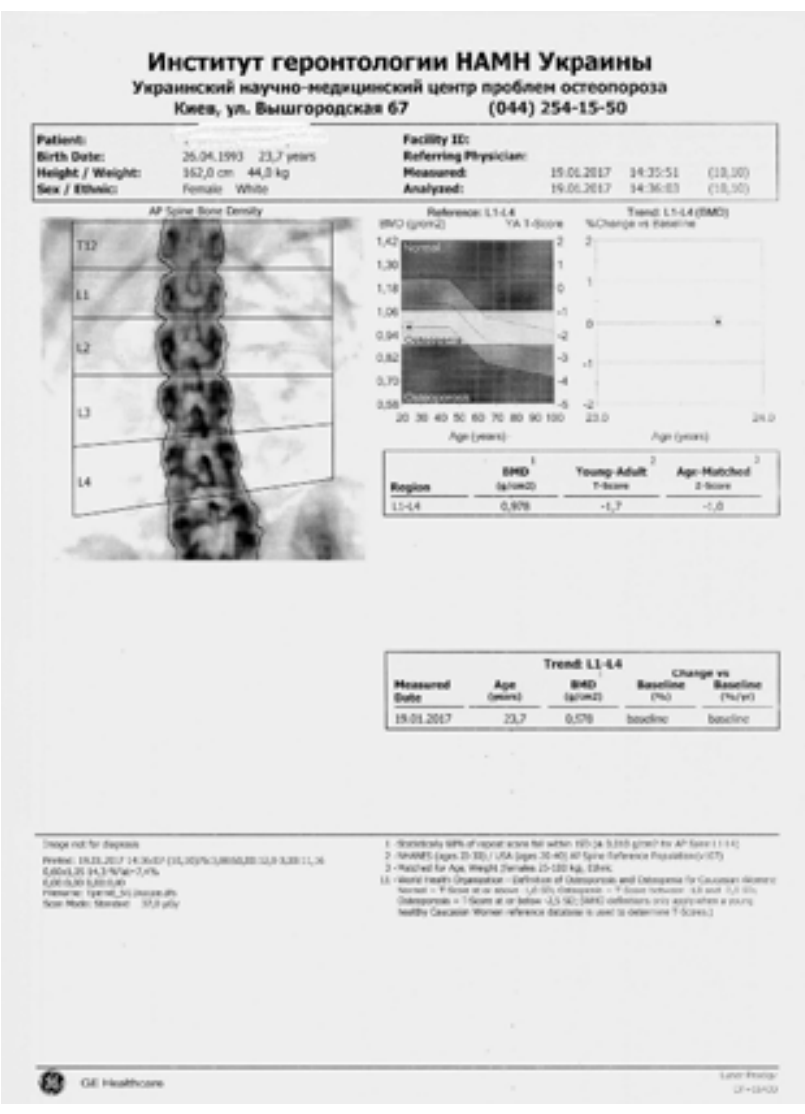

Fig.3. X-ray absorptiometry protocol of the patient K. 
studies: ionized calcium $1.2 \mathrm{mmol}$, phosphorus 0.87 $\mathrm{mmol} / \mathrm{l}$, PTH $86.2 \mathrm{pmol} / \mathrm{l}$, creatinine $123 \mu \mathrm{mol} / \mathrm{l}$, GFR $53 \mathrm{ml} / \mathrm{min} / 1.73 \mathrm{~m}^{2}$. Conclusion of the X-ray densitometry (Fig. 3): the deviation of the mineral density index of bone tissue (T-score) corresponds to osteopenia.

Tactics of management of the patient by the urologist: percutaneous contact fragmentation of a concretion. After the treatment in urology, the recommendations for the treatment of osteopenia are followed: taking calcium and vitamin D supplements, but in view of the decrease in GFR in order to correct secondary hyperparathyroidism, active metabolites of vitamin $\mathrm{D}$ are required (should be started with low doses, independent of the initial PTH concentration, and then titrated based on the PTH response. Hypercalcemia should be avoided.)

Discussion. Prevention and treatment of secondary hyperparathyroidism is important because imbalances in mineral metabolism are associated with CKD-OP, and higher PTH levels are associated with increased morbidity and mortality in CKD patients. For many decades, calcitriol and other vitamin D analogs have been the primary therapeutic option for treating secondary hyperparathyroidism in individuals with CKD.

On the other hand, conditions that lead to chronic kidney disease lead to a decrease in glomerular filtration rate, which inhibits the process of conversion of vitamin $\mathrm{D}$ into the active form - D-hormone, activating the production of PTH, which will accelerate bone resorption with the development of renal osteopathies (Pludowski et al., 2018). Thus, the occurrence of secondary hyperparathyroidism is a significant predictor of the development of disorders of the structural and functional state of bone tissue. When it is in deficiency, rickets or osteomalacia develop (Povoroznyuk et al., 2017).

The precursor of cholecalciferol, provitamin D3, is synthesized in the epidermis from provitamin D3 (7-dehydrocholesterol) under the influence of ultraviolet light. Provitamin D3 is converted to cholecalciferol by thermal isomerization (at body temperature). In the epidermis, cholecalciferol binds to vitamin D-binding protein and in this form enters the bloodstream and is transferred to the liver. Vitamin-D-binding protein transports other derivatives of cholecalciferol and ergocalciferol, including $1.25(\mathrm{OH}) 2 \mathrm{D} 3$. Cholecalciferol is found in many products. It is especially rich in fish oil, liver of birds, birds and fish, as well as in egg white. Ergocalciferol is formed in the cells of ergosterol plants. Cholecalciferol and ergocalciferol are hormonally inactive. In the liver, cholecalciferol and ergocalciferol are converted to 25 (OH) D3 (25-hydroxyvitamin D3, calcidiol) by 25-hydroxylation. $25(\mathrm{OH}) \mathrm{D} 3$ - the main circulating metabolite of cholecalciferol and ergocalciferol. Therefore, the concentration of $25(\mathrm{OH}) \mathrm{D} 3$ can be judged by the content in the body of all forms of vitamin D. Formed 25 $(\mathrm{OH}) \mathrm{D} 3$ in combination with vitamin-D-binding protein in cells of proximal convoluted tubules, $25(\mathrm{OH}) \mathrm{D} 3 \mathrm{un}$ dergoes hydroxylation. As a result, a hormonally active form of vitamin D-1,25 $(\mathrm{OH}) 2 \mathrm{D} 3$ (calcitriol - D-hormone) is formed, which is catalyzed by the mitochondrial enzyme 1- $\alpha$ hydroxylase (Cheng et al., 2017). Like $\mathrm{PTH}$, the D-hormone calcitriol-1.25 $(\mathrm{OH}) 2 \mathrm{D} 3$ regulates bone remodeling and stimulates calcium absorption in the intestine thereby supporting mineralization.

Conclusion. The development of tactics for the treatment of patients with comorbid pathology - various degree of disturbance of mineral density of a bone and KSD is a topical issue and requires the introduction of special algorithms depending on the situation.

Patients with KSD should be determined for calcium-phosphorus metabolism, PTH and vitamin D levels, and X-ray absorptiometry for the purpose of appointment.

In order to prevent the development of KSD in patients with reduced glomerular filtration rate and secondary hyperparathyroidism, it is necessary to prescribe active metabolites of vitamin D and anti-osteoporotic drugs.

Financing.This study did not receive funding

Conflict of interest. None of the authors received research grants, speaker's fees from any companies and is not a member of commissions.

Authors contribution: concept, methodology, formal analysis - K.I., N.O.; research, resources, data curation, written - N.O., S.P.; original project preparation, review and editing, visualization, supervision, project administration, acquisition of financing - K.I., N.O., N.O., S.P.

Consent to publication. All authors have read and approved the final version of the manuscript. All authors have agreed to publish this manuscript.

\section{LITERATURE}

Bijelic, R., Milicevic, S., \& Balaban, J. (2016). Correlation of Osteoporosis and Calcium Urolithiasis in Adult Population. Medical archives (Sarajevo, Bosnia and Herzegovina), 70(1), 66-68.

Cheng, Y. B., Li, L. H., Guo, Q. H., Li, F. K., Huang, Q. F., Sheng, C. S., Wang, J. G., Staessen, J. A., \& Li, Y. (2017). Independent effects of blood pressure and parathyroid hormone on aortic pulse wave velocity in untreated Chinese patients. Journal of hypertension, 35(9), 1841-1848.

Harvey, N. C., Biver, E., Kaufman, J. M., Bauer, J., Branco, J., Brandi, M. L., Bruyère, O., Coxam, V., Cruz-Jentoft, A., Czerwinski, E., Dimai, H., Fardellone, P., Landi, F., Reginster, J. Y., Dawson-Hughes, B., Kanis, J. A., Rizzoli, R., \& Cooper, C. (2017). The role of calcium supplementation in healthy musculoskeletal ageing : An expert consensus meeting of the European Society for Clinical and Economic Aspects of Osteoporosis, Osteoarthritis and Musculoskeletal Diseases (ESCEO) and the International Foundation for 
Osteoporosis (IOF). Osteoporosis international : a journal established as result of cooperation between the European Foundation for Osteoporosis and the National Osteoporosis Foundation of the USA, 28(2), 447-462.

Khan, A. A., Hanley, D. A., Rizzoli, R., Bollerslev, J., Young, J. E., Rejnmark, L., Thakker, R., D’Amour, P., Paul, T., Van Uum, S., Shrayyef, M. Z., Goltzman, D., Kaiser, S., Cusano, N. E., Bouillon, R., Mosekilde, L., Kung, A. W., Rao, S. D., Bhadada, S. K., Clarke, B. L.. ... Bilezikian, J. P. (2017). Primary hyperparathyroidism: review and recommendations on evaluation, diagnosis, and management. A Canadian and international consensus. Osteoporosis international : a journal established as result of cooperation between the European Foundation for Osteoporosis and the National Osteoporosis Foundation of the USA, 28(1), 1-19.

Pludowski, P., Holick, M. F., Grant, W. B., Konstantynowicz, J., Mascarenhas, M. R., Haq, A., Povoroznyuk, V., Balatska, N., Barbosa, A. P., Karonova, T., Rudenka, E., Misiorowski, W., Zakharova, I., Rudenka, A., Łukaszkiewicz, J., Marcinowska-Suchowierska, E., Laszcz, N., Abramowicz, P., Bhattoa, H. P., \& Wimalawansa, S. J. (2018). Vitamin D supplementation guidelines. The Journal of steroid biochemistry and molecular biology, 175, 125-135.

Povoroznyuk, V. V., Pludowski, P., Holick, M., Balatska, N. I., Dzerovych, N. I., Solonenko, T. Y., \& Ivanyk, O. S. (2017). 25-hydroxy vitamin d levels, vitamin d deficiency and insufficiency in patients with boneand musculoskeletal disorders. Боль. Суставы. Позвоночник, 7(3).

Rendina, D., De Filippo, G., Iannuzzo, G., Abate, V., Strazzullo, P., \& Falchetti, A. (2020). Idiopathic Osteoporosis and Nephrolithiasis: Two Sides of the Same Coin?. International journal of molecular sciences, 21(21), 8183.

Taguchi, K., Hamamoto, S., Okada, A., Tanaka, Y., Sugino, T., Unno, R., Kato, T., Ando, R., Tozawa, K., \& Yasui, T. (2020). Low bone mineral density is a potential risk factor for symptom onset and related with hypocitraturia in urolithiasis patients: a single-center retrospective cohort study. BMC urology, 20(1), 174.

\section{СЕЧОКАМ'ЯНА ХВОРОБА ТА ОСТЕОПОРОЗ - ГОСТРІ ПИТАННЯ КОМОРБІДНОСТІ}

\author{
Кордубайло Ілля' ${ }^{1}$, Нікітін Олег ${ }^{2}$, \\ Нішкумай Ольга ${ }^{3}$, Самчук Павло $^{4}$ \\ ${ }^{1}$ Студент НМУ ім. О.О.Богомольця, м.Київ, \\ Україна \\ 2 Професор, доктор медичних наук, завідувач \\ кафедри урології НМУ ім. О.О.Богомольця, \\ м.Київ, Україна \\ ${ }^{3}$ Професор кафедри внутрішньої медицини \\ №2, доктор медичних наук, НМУ \\ ім. О.О.Богомольця, м.Київ, Україна \\ ${ }^{4}$ Асистент кафедри урології НМУ \\ ім. .О.Богомольця, м.Київ, Україна
}

Анотація: поширеність сечокам'яної хвороби (CКХ) і остеопорозу (ОП) збільшується 3 кожним роком. У профілактиці остеопорозу велике значення відіграє вживання в добовому раціоні достатньої кількості продуктів, що містять кальцій, а також застосування препаратів кальцію, вітаміну D. Однією 3 важливих причин недостатнього вживання кальцийвмісних продуктів та лікарських засобів $є$ тривога не тільки пацієнтів, але, що дуже важливо, й лікарів, щодо можливого провокування або розвитку СКХ. Це має серйозні обгрунтування, оскільки нефролітіаз зустрічається приблизно у 5\% населення, а ризик утворення каменів в нирках протягом життя становить 8-10\%. Існує думка, що вторинний гіперпаратиреоз, який обумовлений гіпокальциємією внаслідок недостатнього вживання кальцийвмісних продуктів та порушень функції нирок , призводить до посилення кісткової резорбції, формування матриці $з$ подальшим утворенням мікролітів нирок.

\section{МОЧЕКАМЕННАЯ БОЛЕЗНЬ И ОСТЕОПОРОЗ - ОСТРЫЕ ВОПРОСЫ КОМОРБИДНОСТИ}

\author{
Кордубайло Илья ${ }^{1}$, Никитин Олег ${ }^{2}$, \\ Нишкумай Ольга ${ }^{3}$, \\ Самчук Павел Олександрович ${ }^{4}$
}

${ }^{1}$ Студент НМУ им. А.А. Богомольца, г.Киев, Украина

2 Профессор, доктор медицинских наук, заведующий кафедрой урологии НМУ им. А.А.Богомольца, г. Киев, Украина

${ }^{3}$ Профессор кафедры внутренней медицины №2, доктор медицинских наук, НМУ им. А.А. Богомольца, г. Киев, Украина

${ }^{4}$ Ассистент кафедры урологии НМУ им. А.А. Богомольца, г. Киев, Украина

Аннотация: Распространенность мочекаменной болезни (МКБ) и остеопороза (ОП) увеличивается с каждым годом. В профилактике остеопороза большое значення имеет употребление в суточном рационе достаточного количества кальцийсодержащих продуктов, а также использование препаратов кальция и витамина D. Одной из важных причин недостижения суточной потребности в кальции является беспокойство не только пациентов, но и врачей вероятности провокации мочекаменной болезни от приема препаратов кальция. Это имеет серьезное обоснование, поскольку с каждым годом нефролитиаз встречается приблизительно у 5\% населення, а риск образования камней в почках на протяжении жизни составляет 8-10\%. Существует гипотеза, что вторичный гиперпаратиреоз, который обуслобленый гипокальциемией вследствие недостаточного употребления кальцийсодержащих продуктов и наруше- 
Важливо приймати до уваги, що на тлі гіпертензивної, атеросклеротичної хвороби нирок, тубуло-інтерстиціальних уражень нирок при зниженні швидкості клубочкової фільтрації зменшується синтез $1 \alpha-$ гідроксилази - ферменту, за допомогою якого 25-гідроксихолекальциферол $(25(\mathrm{OH}) \mathrm{D} 3$, кальцідіол) перетворюється в активну форму вітаміну D3-1,25 дигідроксихолекальціферол $(1,25(\mathrm{OH}) 2 \mathrm{D} 3$, кальцитріол - D-гормон) і розвивається вторинний гіперпаратиреоз. В такому випадку 3 метою корекції поряд 3 лікуванням сечокам'яної хвороби (санаторно-курортне лікування, застосування сумішей, проведення сеансів дистанційного дроблення конкременту) необхідно призначати активні метаболіти вітаміну D (альфакальцидолу), з подальшим моніторингом рівня іонізованого кальцію, фосфору, паратгормону крові та проведенням рентгенденситометрії.

Ключові слова: сечокам'яна хвороба, остеопороз, гіперпаратиреоз, кальцідіол. ния функции почек, приводят к усилению костной резорбции, формированию матрицы с дальнейшим образованием микролитив почек. Важно принимать во внимание, что на фоне гипертензивной, атеросклеротической болезни почек, тубуло-интерстициальных поражений почек при снижении скорости клубочковой фильтрации уменьшается синтез $1 \alpha$-гидроксилазы - фермента, с помощью которого 25-гидроксиолекальциферол $(25(\mathrm{OH}) \mathrm{D} 3$, форму витамина D3-1,25 дигидроксихолекальциферол $(1,25(\mathrm{OH}) 2 \mathrm{D} 3$, кальцитриол - D-гормон) и развивается вторичный гиперпаратиреоз. В таком случае в целях корекции наряду с лечением мочекаменной болезни (санаторно-курортное лечение, применение смесей, проведення сеансив дистанцийного дроблення конкременту) необхидно назначать активни метаболиты витамину D (альфакальцидолу), с подальшим мониторингом уровня ионизованого кальцию, фосфору, паратгормону крови и проведением рентгенденситометрии.

Целью работы было на клинических примерах рассмотреть различные тактики ведення пациентов с коморбидной патологией - мочекаменной болезнью и различной степенью нарушением минеральной потности костной ткани.

Ключевые слова: мочекаменная болезнь, остеопороз, гиперпаратиреоз, кальцитриол. 